\title{
Actualización: Enfermedad por el virus del Ébola
}

\author{
Ebola virus disease
}

Nadia Musarella*

\begin{abstract}
Resumen
La enfermedad por el virus del Ébola (EVE) es una entidad contagiosa y de alta mortalidad. Se caracteriza por la presencia de fiebre, debilidad, odinofagia, dolor abdominal y muscular, cefalea, vómitos, diarrea, hemorragias y falla multiorgánica. Su reconocimiento temprano es fundamental para controlar la propagación del virus. El tratamiento se basa en las medidas de soporte para controlar las complicaciones producidas por el virus. No existe un tratamiento específico para la EVE ni una vacuna para prevenirla. La prevención de la transmisión de la enfermedad se basa en priorizar los cuidados ambientales y de contacto ante el desarrollo de epidemias.
\end{abstract}

\section{Abstract}

Ebola virus disease (EVD) is a contagious condition with high mortality. It is characterized by the presence of fever, weakness, sore throat, abdominal and muscle pain, headache, vomiting, diarrhea, bleeding and multiple organ failure. Its early recognition is critical to controlling the spread of the virus. Treatment is based on supportive measures to control the complications caused by the virus. There is no specific treatment for EVD and no vaccine to prevent it. The prevention of disease transmission is based on prioritizing environmental and contact care during the development of outbreaks.

Palabras clave: enfermedad por el virus del Ébola, revisión. Key words: Ebola virus disease, review.

Musarella N. Enfermedad por el virus del Ébola. Evid Act Pract Ambul. 2014:17(4).Oct-Dic.136-139.

Introducción

La enfermedad por el virus del Ébola (EVE), es una enfermedad poco común y con elevada mortalidad causada por la infección por una especie del virus Ébola.

En el año 2014 el mundo se enfrentó al brote más grande y complejo de EVE de la historia. La Organización Mundial de la Salud (OMS) declaró a esta epidemia surgida en África Occidental como una emergencia de salud pública de importancia internacional y la calificó como un "evento extraordinario" con riesgos para la salud pública de otros países.

\section{Fisiopatogenia}

Una epidemia por el virus Ébola comienza cuando un individuo se infecta mediante el contacto con los fluidos corporales de un animal infectado (monos, gorilas y chimpancés). Una vez que esa persona se enferma o muere, el virus se disemina a otras personas que están en contacto directo con la sangre, la piel u otros fluidos corporales del enfermo. Se propone que los huéspedes naturales del virus son los murciélagos frugívoros de la familia Pteropodidae.

Después de entrar en el cuerpo a través de las membranas mucosas, las heridas en la piel o por vía parenteral, el virus del Ébola infecta a diferentes tipos de células y se propaga rápidamente en forma sistémica debido a la supresión de las respuestas inmunes que el mismo virus induce. Además de causar daño tisular extenso, el virus promueve un síndrome inflamatorio sistémico mediante la inducción y la liberación de citocinas, quimiocinas y otros mediadores proinflamatorios de los macrófagos y otras células. Esta respuesta inflamatoria sistémica puede jugar un papel importante en la inducción de la disfunción gastrointestinal, la fuga vascular difusa y la insuficiencia multiorgánica que se observa en los estadios más avanzados de la enfermedad. La infección por este virus también conduce a defectos de la coagulación que parecen estar inducidos indirectamente, a través de la misma respuesta inflamatoria del huésped.

\section{Epidemiología}

La EVE es causada por la infección por un virus de la familia Filoviridae, género Ebolavirus que se encuentra en varios países africanos.
Según la OMS, los fluidos corporales más infecciosos son la sangre, las heces y los vómitos. El virus también se puede propagar a través del contacto directo con la piel de un enfermo, aunque el riesgo de desarrollar una infección por este medio es menor. Además, puede transmitirse a través del contacto con superficies y objetos contaminados (ropa, ropa de cama, agujas, jeringas, elementos cortantes o equipo médico). También se ha detectado el virus en la orina, el semen, la saliva, la leche materna, las lágrimas y el sudor de las personas infectadas. El virus o el ARN viral pueden persistir en algunos de estos fluidos, incluso después de que ya no se detecta en la sangre; sin embargo, el riesgo de transmisión de los virus persistente en estos sitios no está bien establecida. Por otro lado, no hay evidencia de que el virus pueda propagarse de persona a persona por vía respiratoria.

El periodo de incubación de la EVE oscila entre dos y 21 días (promedio ocho y 10 días). Si después de 21 días la persona expuesta no tiene síntomas, no se enfermará.

\section{Presentación clínica}

Se caracteriza por la aparición súbita de fiebre, debilidad intensa y dolores musculares, de cabeza y de garganta, seguidos de síntomas gastrointestinales como vómitos y diarrea que a menudo conducen a la pérdida significativa de líquidos y electrolitos. A medida que la enfermedad progresa, se pueden producir erupciones cutáneas, hemorragias, disfunción renal y hepática con falla multiorgánica y shock.

Aproximadamente el $20 \%$ de los pacientes con EVE tiene sangrados. Los más frecuentes ocurren en las heces, pero puede también haber petequias, equimosis, exudación de los sitios de punción venosa y/o hemorragias de las mucosas. El desarrollo de hemorragias mayores no es un hallazgo común en el curso de la enfermedad. En la fase terminal se presentan hemorragias graves como consecuencia de una coagulación intravascular diseminada.

Los enfermos que desarrollan signos y síntomas clínicos graves con progresión a la insuficiencia multiorgánica en la etapa temprana de la infección, habitualmente mueren en la segunda semana.

Los resultados de laboratorio muestran leucopenia, trombocitopenia y elevación de las transaminasas séricas, así como anomalías renales y de la coagulación. Otros hallazgos incluyen una marcada disminución de las proteínas plasmáticas (que refleja un síndrome de fuga capilar) y niveles elevados de amilasemia.

* Servicio de Medicina Familiar y Comunitaria del Hospital Italiano de Buenos Aires. nadia.musarella@ hospitalitaliano.org.ar 


\section{Sistemática de estudio}

Durante una epidemia y ante la sospecha de contagio se recomienda al personal médico evaluar a los pacientes para determinar si tienen hallazgos clínicos compatibles con la enfermedad: fiebre, dolor de cabeza severo, debilidad, dolor muscular, vómitos, diarrea, dolor abdominal o hemorragia inexplicable. Para ello es preciso obtener una historia cuidadosa del riesgo epidemiológico y determinar si han tenido una posible exposición al virus del Ébola, incluyendo una historia de viajes a un país con transmisión generalizada del virus, casos en zonas urbanas con medidas de control dudosas o contacto dentro de los 21 días anteriores con una persona con la EVE mientras la persona presentaba síntomas. El reconocimiento temprano es fundamental para controlar la propagación del virus. Se denomina caso confirmado a aquel en el que se diagnostica por laboratorio la infección por el virus del Ébola. Las pruebas de laboratorio para detectar la presencia de este virus deben realizarse a los pacientes que han estado expuestos al virus y tienen síntomas clínicos y hallazgos de laboratorio compatibles. Las pruebas rápidas de diagnóstico para la infección por el virus de Ébola se basan principalmente en la detección de secuencias específicas de ARN por reacción en cadena de la polimerasa con transcripción inversa (RT-PCR) en la sangre $\mathrm{u}$ otros fluidos corporales del enfermo. Otras pruebas disponibles son la de inmunoadsorción enzimática (ELISA), la detección de antígenos, la prueba de seroneutralización y el aislamiento del virus mediante cultivo celular. El virus de Ébola generalmente es detectable en muestras de sangre dentro de los tres días siguientes a la aparición de los síntomas, por eso puede ser necesario repetir la prueba en aquellos pacientes con síntomas de menos de tres días de evolución. Las muestras de los pacientes suponen un enorme peligro biológico y las pruebas tienen que realizarse en condiciones de máxima contención biológica.

\section{Diagnóstico diferencial}

El diagnóstico diferencial variará notablemente con las circunstancias clínicas y epidemiológicas. Antes de establecer un diagnóstico de EVE es preciso descartar otras entidades como paludismo, fiebre tifoidea, shigelosis, cólera, leptospirosis, peste, rickettsiosis, fiebre recurrente, meningitis, hepatitis y otras fiebres hemorrágicas víricas.

\section{Tratamiento}

No hay un tratamiento específico ni una vacuna para prevenir la enfermedad. Se están desarrollando vacunas y tratamientos experimentales pero aún no se ha podido probar completamente su seguridad y eficacia. Los síntomas y las complicaciones de la EVE se tratan a medida que aparecen. Los casos graves requieren cuidados intensivos.

\section{Medidas generales}

Las siguientes medidas básicas pueden mejorar significativamente la probabilidad de supervivencia del enfermo si se toman desde un comienzo: 1) proporcionar líquidos intravenosos y mantener el equilibrio hidroelectrolítico, 2) mantener los niveles adecuados de oxígeno y presión arterial, 3) tratar otras infecciones que se presenten. Todos los pacientes que tienen o en los que se sospecha EVE se deben aislar con prontitud. Se debe contactar inmediatamente al personal de control de infecciones del hospital, así como al departamento de salud local o estatal. También es preciso realizar el seguimiento de los síntomas y signos de la EVE en las personas asintomáticas que han estado expuestas al virus en cualquier nivel de riesgo. La recuperación de la EVE depende de un buen cuidado de soporte y de la respuesta inmune del paciente. Aquellos que sobreviven comienzan a mejorar durante la segunda semana de la enfermedad. El período de convalecencia se presenta con marcada debilidad, fatiga y fracaso para recuperar el peso que se perdió durante la enfermedad. Se produce una amplia descamación de la piel y pérdida de cabello debido a la necrosis de las glándulas sudoríparas infectadas y de otras estructuras dérmicas inducida por el virus. Durante la convalecencia, el ARN viral y virus infecciosos pueden persistir en ciertos fluidos corporales (por ejemplo, orina, semen). Las personas que se recuperan producen anticuerpos que duran por lo menos diez años (posiblemente más). Se desconoce si quienes logran recuperarse son inmunes de por vida o si pueden infectarse con diferentes especies del virus. Algunas de las personas que se recuperaron han desarrollado complicaciones a largo plazo, como problemas articulares y de visión por la formación de complejos antígeno-anticuerpo.

\section{Prevención}

Hasta el momento no existe una vacuna contra la EVE. Se recomienda aplicar las precauciones generales cuando se atienda y trate a cualquier paciente, independientemente de que sea un caso de infección presunta o confirmada. Estas precauciones representan el nivel básico de control de las infecciones e incluyen la higiene de las manos, el uso de equipo de protección personal para evitar el contacto directo con sangre y líquidos corporales, la prevención de los pinchazos de aguja y las lesiones con otros instrumentos cortopunzantes y un conjunto de medidas de control ambiental. En la figura 1 se presenta un algoritmo de diagnóstico, notificación y disposición de personas en las que se sospeche contacto con EVE elaborado por el Ministerio de Salud de la Nación Argentina.

\section{Consejo y educación}

Ante la falta de un tratamiento eficaz y de una vacuna, la concientización sobre los factores de riesgo y las medidas de protección es la única forma de reducir el número de infecciones y muertes. A nivel de la salud pública los cuidados se deben centrar en:

- Reducir el riesgo de transmisión de animales salvajes al ser humano como consecuencia del contacto con murciélagos frugívoros o simios infectados y del consumo de su carne cruda. Deben utilizarse guantes y otras prendas protectoras apropiadas para manipular animales.

- Reducir el riesgo de transmisión de persona a persona a consecuencia del contacto directo o estrecho con pacientes infectados, especialmente con sus líquidos corporales.

- Evitar el contacto físico estrecho con pacientes con EVE y utilizar guantes y equipo de protección personal adecuado para atender a los enfermos en el hogar.

- Lavarse las manos con regularidad tras visitar a enfermos en el hospital, así como después de cuidar a enfermos en el hogar.

- Las comunidades afectadas por la EVE deben informar a la población acerca de la naturaleza de la enfermedad y de las medidas de contención de los brotes, en especial la inhumación de las personas fallecidas. Los enfermos que mueren por esta causa deben ser sepultados rápidamente y en condiciones de seguridad.

Para obtener más información actualizada referente al manejo de casos de EVE se recomienda al lector recurrir a los links disponibles en el apartado de referencias bibliográficas. 
Figura 1: algoritmo de diagnóstico, notificación y disposición de personas en las que se sospeche contacto con EVE.

\section{Algoritmo de diagnóstico y notificación ENFERMEDAD POR VIRUS EBOLA (EVE)

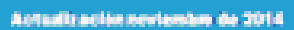

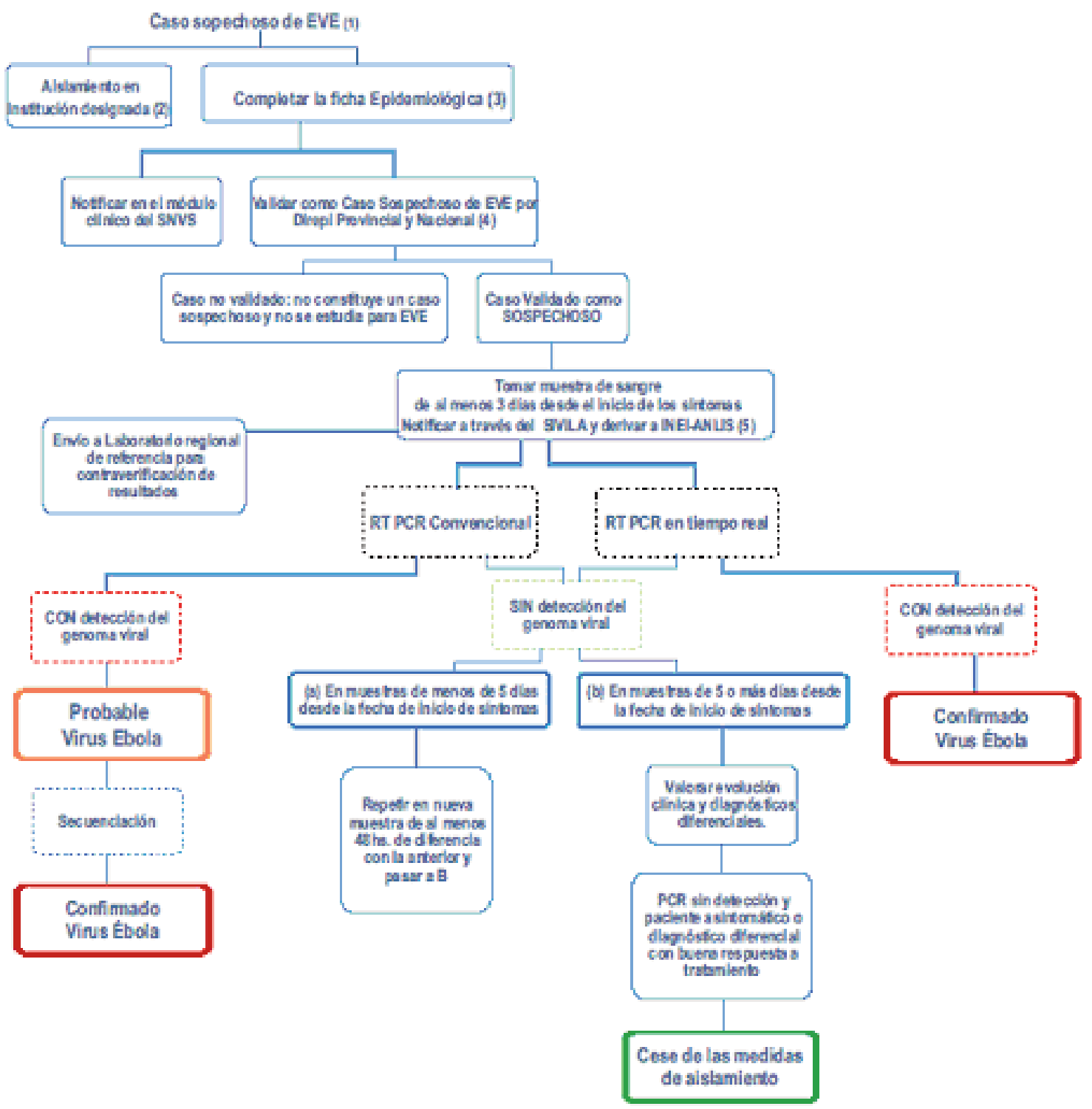

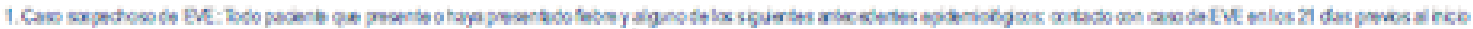

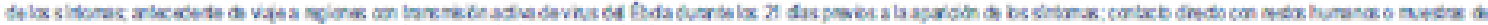

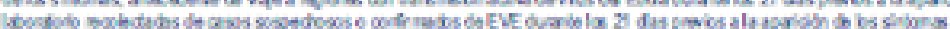

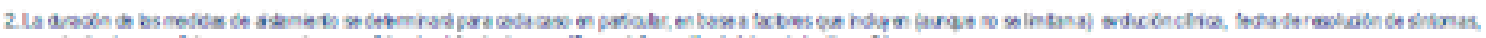

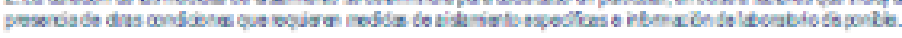

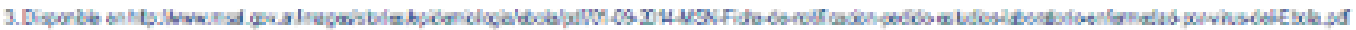

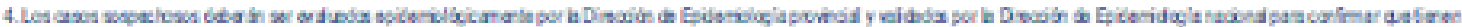

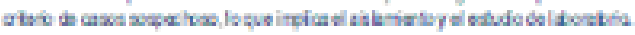




\section{Referencias bibliográficas}

-World Health Organization. Global Alert and Response. Ebola virus disease (en línea). Disponible en: http://www.who.int/csr/disease/ebola/en/ (último acceso diciembre 2014). -United States Centers for Disease Control and Prevention (CDC). Ebola (Ebola Virus Disease) (en linea). Disponible en:

http://www.cdc.gov/vhf/ebola/ (último acceso diciembre 2014).

-World Health Organization. Clinical management of patients with viral haemorrhagic fever: A pocket guide for the front-line health worker (en línea). 2014. Disponible en: http://apps.who.int/iris/bitstream/10665/130883/2/WHO_HSE_PED_AIP_14.05.pdf?ua=1 (último acceso diciembre 2014).

-Centers for Disease Control and Prevention. Questions and answers on Ebola (en línea). Disponible en: http://www.cdc.gov/vhf/ebola/outbreaks/guinea/qa.html (último acceso diciembre 2014).

-Ministerio de Salud de la Nación. Algoritmo de diagnóstico y notificación Enfermedad por Virus Ebola (en línea). Disponible en: http://www.msal.gov.ar/images/stories/epidemiologia/ebola/pdf/11-2014-algoritmo-diagnostico-notificacion-ebola.pdf (último acceso diciembre 2014) 